\title{
The economic impact of museums on local economies
}

\author{
André M. Levesque, Ec.D.
}

\begin{abstract}
As generalists, economic developers are cognisant of the tourism industry but very few consider themselves experts in determining and estimating the economic impact of museums in their local area. In comparison to other professionals in the tourism and museum fields, economic developers have written relatively little on this topic and consequently, this paper will examine how cultural institutions impact local economies in the long and short term. A general profile of Canada's heritage institutions is presented, followed by a review of an exhibition which set a national standard. The final case study is on Ottawa-Hull's federally funded museums. The paper concludes with a number of policies that can be applied to communities to develop a successful tourism sector.
\end{abstract}

Keywords: museum, tourism, heritage institutions, Ottawa-Hull

\section{Introduction}

As generalists, economic developers are cognisant of the tourism industry but very few consider themselves experts in determining and estimating the economic impact of museums in their local area. In comparison to other professionals in the tourism and museum fields, economic developers have written relatively little on this topic and consequently, this paper will examine how these cultural facilities affect this economic sector in both the short and long terms. A general profile of Canada's heritage institutions will be presented, followed by a review of an exhibition which set a national standard. The final case study used is our Nation's Capital as it has a wide assortment of federally funded museums. The issue of museum web sites as generators of revenue will also be examined. The paper examines how these cultural institutions impact on local economies which will help better understand this specialized industry.

\section{Heritage facilities as tourist attractions}

The concept of museums has existed for a very long time. Ancient cities drew people together and strengthened civic pride in what their communities had to offer to both residents and visitors alike. With their relaxing baths and spas, splendid architecture, and striving commerce, Roman culture and heritage flourished to become the cornerstone for the advancement of their civilization. The Romans established the idea of educating their people on their past and their civil and military accomplishments. In many ways, the promotion of their way of life acted as an economic catalyst. Along with visiting ancient sites came the provision of accommodations, 
food and souvenirs as mementos.

Nine hundred years after the Great Crusades, the economic impact of tourism remains an important factor in far away places such as the Holy Land. Be it a visit to Rome's Parthenon or Jerusalem's Church of the Holy Sepulchre, the apparent birth place of Jesus Christ, attendance at such heritage institutions remains an essential component embracing the vestige of other cultures. Somehow, the ancient cliché of "when in Rome -- do like the Romans" still seems to apply when one wanders out of known territory.

For the purpose of collecting data, Statistics Canada utilizes the term "heritage institutions" which include museums, historic sites, archives, and other related institutions such as exhibition centres, planetariums, and observatories, aquariums and zoos, and botanical gardens, arboretums and conservatories. ${ }^{1}$ Within the literature, museums and art galleries are often referred to as "cultural institutions" and also include other "organizations that seek to educate, inform and perhaps even entertain the public through some sort of collections-based acquisition and research activity."2

Notwithstanding the similarities between heritage and cultural institutions, there are nevertheless differences in the types of museums that are being operated. While some operate as major (anchor) institutions, there are others that are more complimentary in nature. It is generally accepted that the larger, more established museums have a greater impact on the local economy. While major institutions are more predominant in terms of levels of revenues and expenditures, complimentary institutions also play an important role, particularly in less urbanized areas.

Figure 1. Museum as a living structure

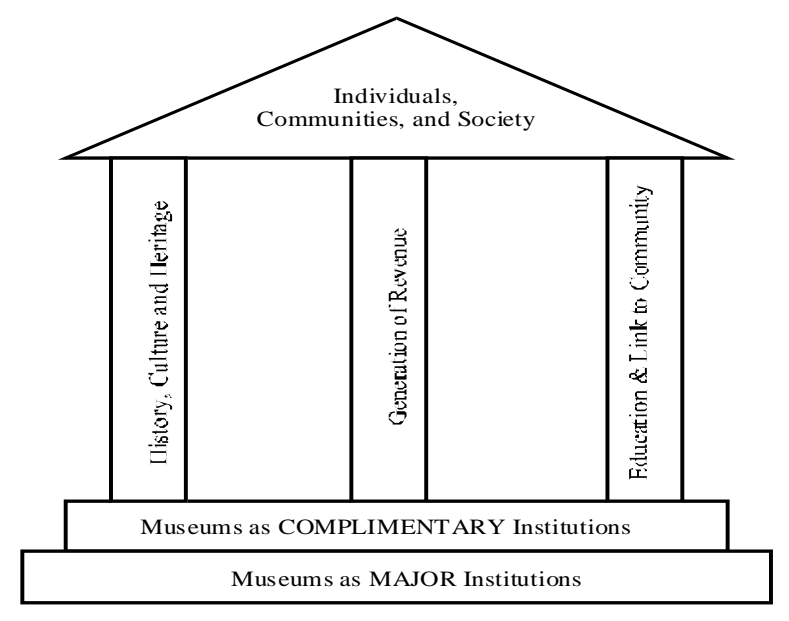

\footnotetext{
${ }^{1}$ Statistics Canada, The Daily, Heritage Institutions publications released Monday, March 9, 1998, web site.

${ }^{2}$ Linton, Jon, “Tomorrow’s Museum Audiences - Key Challenges to Audience Development,” Canadian Museums Association, Vol. XI, No. 2, Summer 1993, September Issue, p. 1, web site.
} 
A museum can be viewed as a living structure composed of intricate parts that hold it together. In the figure presented above, it is the three pillars that integrate society and museums into cultural institutions. The pediment forms the basis of all those who visit these institutions. The leading steps are the physical institutions themselves: the bricks and mortar make up the various exhibits, the researchers, the historians and the administrators who operate the facility. Without history, culture and heritage, there would be little reason for museums to exist. Without the generation of revenue, museums could not function. Without an education program and a link to the community, the existence of the institution would be unknown. All of these features contribute to the viability of the museum.

\section{Tourism as an industry}

Canada has unique, world class heritage, historical, and cultural attributes and remains a popular destination worldwide. On August 16, 1999, the World Tourism Organization announced that it had ranked Canada eighth in tourism arrival -- one rank higher than the previous year. At the current pace, Canadian Tourism officials expect tourism expenditures to reach $\$ 50$ billion by $2000 .^{3}$

Dr. David Foot, an economist and demographer popularized the study of demographic change and its effect on society. In his book Boom, Bust and Echo, he predicted the behaviour patterns of various age groups. Dr. Foot identified upmarket travel and eco-tourism as major growth areas for aging baby boomers. ${ }^{4}$ As the most appealing travel market segment in Canada, 500,000 baby boomers will pass from middle-age to retirement each year for the next twenty years, with more leisure time and discretionary income for travelling. ${ }^{5}$ It is important to note that such potential growth is not limited only to affluent individuals in their late 40s and older but to other age groups as well. As they age, young people are increasingly shifting their energies to lighter types of activities. Museums are flexible as they provide both active and passive pursuits in a variety of settings. A lot has changed since the opening of the first museum in Canada by Thomas Barnett, who marketed his museum in Niagara Falls, Ontario in $1831 .{ }^{6}$ The following is a brief profile of Canada's heritage institutions which include museums.

From 1991 to 1996, Statistics Canada's profile of heritage institutions pointed to minor fluctuations but overall, visitation trends appeared relatively consistent. The most recent heritage institutions statistics released by Statistics Canada on March 9, 1998 are employed in this paper. ${ }^{7}$ Although attendance at heritage institutions in 1995-96 peaked at nearly 113 million visitors,

\footnotetext{
${ }^{3}$ Ottawa Tourism and Convention Authority, “Canada's Capital Region Tourism Update \& Outlook,” ${ }^{\text {st }}$ Quarter 1999, p. 5.

${ }^{4}$ Foot, David K., Boom, Bust and Echo, p. 121.

${ }^{5}$ Canadian Tourism Commission, 1999/2000 Communications Plan, Canadian Leisure Market, p. 8.

${ }^{6}$ Canadian Museums Association, “About Museums,” web site.

7 Statistics Canada, The Daily, Heritage Institutions publication, web site; and Statistics Canada, "Profile of Heritage Institutions: 1991-92 to 199596,” web site.
} 
these figures are somewhat misleading since a good portion of this attendance (58.5 million or 51.8 per cent) included people visiting one of the 172 nature parks found in Canada.

Consequently, nature parks have been excluded from all heritage institutions figures included herein. Statistics Canada provides a general profile of Canada's heritage institutions as follows.

\begin{tabular}{|c|c|}
\hline - All heritage institutions (excluding nature parks): & 2,390 \\
\hline - Employment (includes full-time and part-time): & 23,173 \\
\hline Volunteer work force: & 52,000 \\
\hline - Attendance (thousands): & 54,482 \\
\hline - Revenues (\$ thousands): & 641,855 \\
\hline - Expenditures (\$ thousands): & 646,119 \\
\hline
\end{tabular}

Excluding nature parks, Canadian heritage institutions can be further subdivided to include museums (community, art, history), historic sites and archives. Some of the key factors which are important to note in trying to evaluate the economic impact of museums on local economies include: attendance, revenues, expenditures, employment and number of heritage institutions. The following charts and table of ratios provide a good insight on the economic impact of museums. It is important to note that variations exist between different types of heritage institutions.

On a per capita basis, the archives category has the highest revenues/attendance ratio $(188: 1)$ but notably the lowest number of visitors $(641,000)$; it only represents 1.2 per cent of the entire visitation for heritage institutions. The art museums category has the highest revenues/attendance ratio at $33: 1$. Considering that such museums account for approximately more than one fifth (21.4 per cent) of all types of museums, their impact on the local economy should be significant. A ratio for revenues/attendance that falls within the $20: 1$ (for all heritage institutions) and the $24: 1$ (for all types of museums) range appears to be within the norm.

With respect to operating expenditures and revenues for museums, the "all types of museums" category is exactly in line with the overall average for all heritage institutions $(1: 0.993$ and 1 : 0.992, respectively). A value in excess of one indicates that the museum is operating within a budget surplus. A value of less than one suggests that they are operating within a budget deficit. The only institutions that are operating above the overall average are community museums, history museums and historical sites. Coincidentally, they are also operating at a budget surplus. 
Figure 2. Revenues for all heritage institutions 1995-1996 (excluding nature parks)

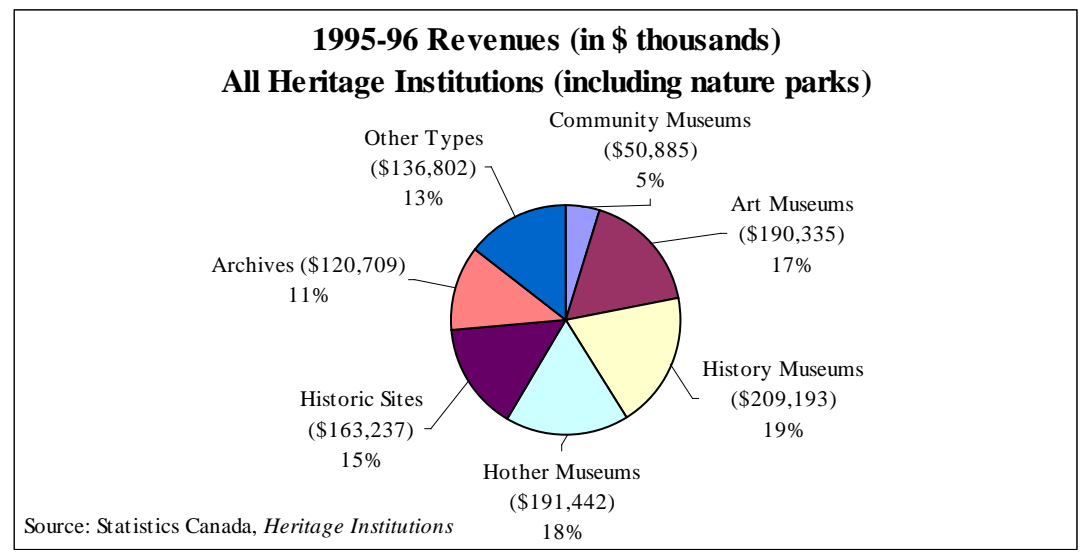

Figure 3. Attendance for all heritage institutions 1995-1996 (excluding nature parks)

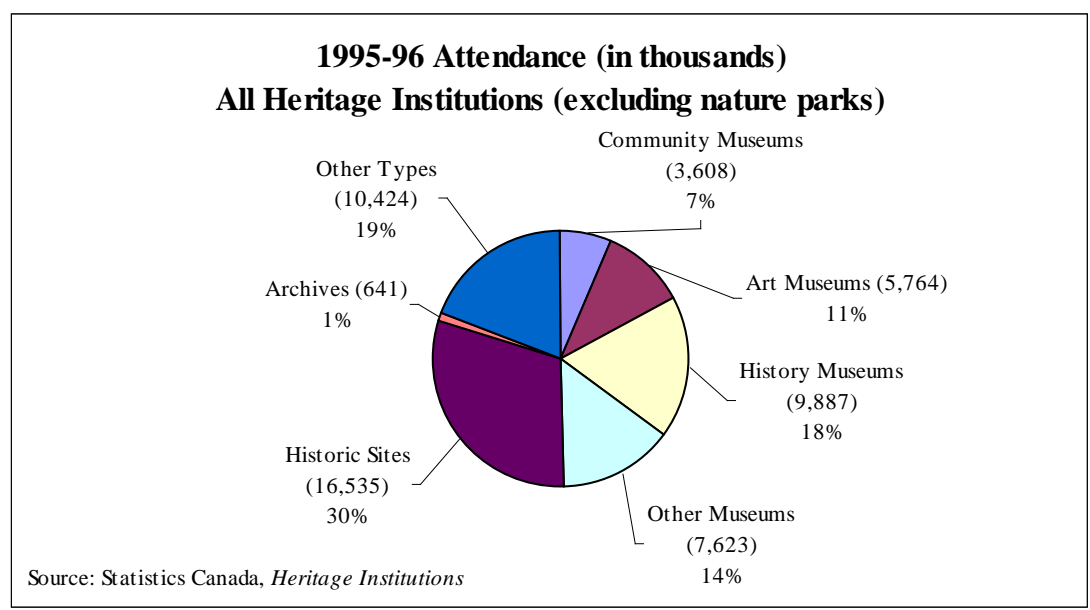

Table 1. Ratios for all heritage institutions 1995-96 (excluding nature parks)

\begin{tabular}{|l|l|l|l|}
\cline { 2 - 4 } \multicolumn{1}{c|}{} & $\begin{array}{l}\text { Revenues } \\
\text { vs. } \\
\text { Attendance }\end{array}$ & $\begin{array}{l}\text { Expenditures } \\
\text { vs. } \\
\text { Revenues }\end{array}$ & $\begin{array}{l}\text { Employment } \\
\text { vs. } \\
\text { Institutions }\end{array}$ \\
\hline Community Museums & $14.103: 1$ & $1: 1.018$ & $3.043: 1$ \\
\hline Art Museums & $33.021: 1$ & $1: 0.974$ & $13.247: 1$ \\
\hline History Museums & $21.158: 1$ & $1: 1.023$ & $11.648: 1$ \\
\hline Other Museums & $25.114: 1$ & $1: 0.975$ & $20.145: 1$ \\
\hline All types of Museums & $23.877: 1$ & $1: 0.993$ & $8.317: 1$ \\
\hline Historic Sites & $9.872: 1$ & $1: 1.021$ & $12.781: 1$ \\
\hline Archives & $188.314: 1$ & $1: 0.913$ & $6.269: 1$ \\
\hline Other types & $13.124: 1$ & $1: 0.828$ & $18.706: 1$ \\
\hline All Heritage Institutions & $20.100: 1$ & $1: 0.992$ & $9.696: 1$ \\
\hline
\end{tabular}


Note: Employment figures includes full-time and part-time.

Source: Derived from Statistics Canada, "Profiles of Heritage Institutions," web site.

With regard to the employment/institutions ratios, the "all types of museums" category is slightly below the national average (8.3 compared to 9.7). As expected, per institution, community museums employ the least number of staff. There exists a wide variation (17 point difference) among the various types of museums. It also appears that the best opportunities for employment at heritage institutions are in the "other museums" category (20:1) and "other types” category (19 : 1). Fair potential for employment includes art museums, historic sites, and history museums that have ratios within range of $11: 1$ and $13: 1$.

\section{The Tutankhamun exhibit}

Today’s museums often organize special exhibits as a way of promoting and rejuvenating themselves. More correctly, these exhibits provide heritage institutions with a superb opportunity to generate revenues from otherwise untapped sources. A wide target audience along with corporate sponsorships meant for many museums the difference between feast and famine. Unlike Americans and Europeans, Canadians normally did not queue for attending museum events -- that is, until the arrival of the treasures of Tutankhamun in Toronto on November 1, 1979. ${ }^{8}$ This event is particularly meaningful as it was Canada's largest museum exhibition. It basically set a national standard on how success can be well managed.

Hosted for two months at the Art Gallery of Ontario, this exhibition of international artifacts had an enormous impact on the local community, both socially and economically. The local media played a large role in influencing people in attending the event. In order to accommodate the large crowds which were expected, the site was open from 8:00 a.m. to 11:00 p.m., seven days a week. ${ }^{9}$ Although people came from a wide geographic area, the exhibit served a large (56 per cent) relatively local market. However, it is important to note that because the number of visitors was very large, a small proportion represented large numbers of people who had a considerable economic impact on the visited city. ${ }^{10}$ As a short-term effect, 86 per cent of the visitors suggested that they visited Toronto primarily for the exhibit. ${ }^{11}$ As a long-term effect, 59 per cent indicated that they would like to return to Toronto for a vacation. ${ }^{12}$

Approximately 800,000 tickets were available for distribution for the exhibition: 450,000 public tickets were sold; 200,000 visitors purchased tickets through various heritage institutions; 100,000 children gained admission through school tours; and 50,000 visitors attended as

\footnotetext{
${ }^{8}$ Wall, Geoffrey and Chris Knapper, Tutankhamun in Toronto, p. 4.

${ }^{9}$ Ibid, p. 7.

${ }^{10}$ Ibid, p. 29.

${ }^{11}$ Ibid, p. 31.
} 
corporate guests. For the purpose of calculating the economic impact of the exhibition, a figure of nearly 700,000 visitors, who purchased tickets either directly or indirectly, was used. The results of a detailed survey examining the impact of the exhibition were published as Tutankhamun in Toronto in 1981. A summary of visitor statistics are provided below:

\section{Table 2. Summary of visitor statistics}

\begin{tabular}{|l|l|l|}
\hline Visitor Category & Number & Percentage \\
\hline Toronto resident & 299,093 & 43.9 \\
\hline Out-of-town day visitor & 255,490 & 37.5 \\
\hline Out-of-town overnight visitor & 126,723 & 18.6 \\
\hline Total & 681,306 & $100.0^{*}$ \\
\hline
\end{tabular}

*excludes school parties

Source: Geoffrey Wall and Chris Knapper, Tutankhamun, p.50.

An estimate of economic impact was also calculated and visitors’ expenditures can be summarized in the following tables.

\section{Table 3. Minimum visitor expenditures}

\begin{tabular}{|l|l|l|l|}
\cline { 2 - 4 } \multicolumn{1}{c|}{} & $\begin{array}{l}\text { Out-of-town } \\
\text { Overnight }\end{array}$ & $\begin{array}{l}\text { Out-of-town } \\
\text { Day }\end{array}$ & Toronto Residents \\
\hline Food & $\$ 2,355,240$ & $\$ 2,322,400$ & $\$ 1,303,117$ \\
\hline Accommodation & $\$ 1,328,653$ & - & - \\
\hline Entertainment & $\$ 407,748$ & $\$ 7,324$ & $\$ 24,387$ \\
\hline Tourist Attractions & $\$ 147,203$ & $\$ 172,137$ & $\$ 19,322$ \\
\hline Transportation & $\$ 2,164,310$ & $\$ 1,280,785$ & $\$ 677,195$ \\
\hline Tutankhamun Souvenirs & $\$ 4,076,186$ & $\$ 4,513,110$ & $\$ 3,884,578$ \\
\hline Other Purchases & $\$ 3,137,910$ & $\$ 1,268,558$ & $\$ 415,270$ \\
\hline Total of Above & $\$ 13,617,250$ & $\$ 9,564,314$ & $\$ 6,323,869$ \\
\hline $\begin{array}{l}\text { All Expenditures as estimated } \\
\text { by visitors }\end{array}$ & $\$ 12,784,577$ & $\$ 6,978,867$ & $\$ 2,855,726$ \\
\hline
\end{tabular}

Source: Geoffrey Wall and Chris Knapper, Tutankhamun, p.50.

When the tables of ratios for this exhibition are compared with attendance at all national heritage institutions, some similarities are noted. In this paper, for comparative purposes, visitor expenditures can be interpreted to be the same as revenues for the particular heritage institution.

\footnotetext{
${ }^{12}$ Ibid, p. 32.
} 
On a per capita basis, the expenditures/attendance ratios for the Tutankhamun exibition (Toronto and Out- of-Town Day categories) are similar to those found for history and art museums at the national level (21-33: 1 and 21-37 : 1, respectively). Moreover, when one considers all types of visitors at the exhibition, the ratio is double that of the ratio for local residents (43:1 and $21: 1$, respectively). The type of visitors that have the highest economic impact are those who are from out-of-town and stay overnight. With an expenditures/attendance ratio of $107: 1$, this group has a significant influence on the local economy. It is worth noting that although they only represent 18.6 per cent of all visitors, they account for 44.6 per cent or nearly half of all expenditures.

\section{Table 4. Table of ratios for visitor expenditures}

\begin{tabular}{|l|l|}
\hline Type of Visitors & Expenditures vs. Attendance \\
\hline Out-of-town Overnight & $107.457: 1$ \\
\hline Out-of-town Day & $37.435: 1$ \\
\hline Toronto Residents & $21.143: 1$ \\
\hline All Categories & $43.307: 1$ \\
\hline $\begin{array}{l}\text { Note: Total expenditure for all types of visitors is } \$ 29,505,433 . \\
\text { 681,306. The total number of visitors is }\end{array}$ \\
\hline
\end{tabular}

Source: Derived from Geoffrey Wall and Chris Knapper, Tutankhamun, p. 50.

Lastly, it was also observed that when visitors were asked to estimate their level of expenditures, the amount was always underestimated ranging from 6.1 per cent for visitors out-of-town overnight, 27.0 per cent for visitors out-of-town day, and 54.8 per cent for the local Toronto residents. Clearly, out-of-town visitors have a better grasp of keeping tract of how much they spend in the local economy. Now that we have examined tourism as an industry, let us explore how cultural institutions impact on the economy of the Ottawa-Hull area.

\section{Tourism in the national capital region}

Given that the Nation's Capital is an exception with respect to the number and quality of nationally funded museums, federal cultural institutions have a major impact on the local economy. The variety of museums and other heritage institutions within the area is certainly unique.

During the 1980s and 1990s, one of the contributions of the National Capital Commission NCC (a Federal agency tasked with a special responsibility for planning the Nation's Capital) was to help promote the location of new cultural institutions in the National Capital Region (NCR). ${ }^{13}$ The relocation of the National Gallery of Canada and the inauguration of the Canadian

\footnotetext{
${ }^{13}$ National Capital Commission, A Capital in the Making, p. 100.
} 
Museum of Civilization in 1988 were significant achievements in themselves. The NCC continues to be a significant player in affecting how and where local federal museums are to operate and locate. In 1993, they formed a partnership called the Federal Task Force on Cooperative Programing and Marketing. Their mandate was to formulate a coherent approach to federal programming and explore the potential for establishing additional strategic partnerships among the participating agencies. ${ }^{14}$ Some of the participants include:

- House of Commons

- Canadian Museum of Civilization

- Canadian War Museum

- National Gallery of Canada

- Canadian Museum of Nature

- Canadian Museum of Science and Technology

- National Archives of Canada

- National Arts Centre

- National Library of Canada

- Royal Canadian Mint

- Supreme Court of Canada

- Currency Museum - Bank of Canada

- Government House - Rideau Hall

Given the advantages of pooling the federal financial, human and information resources, this Task Force has access to 24 different federal partners.

Although the Ottawa-Hull tourism industry is highly fragmented, there are a number of other tourism related organizations who cooperate in the production of deliverables, including the Ottawa Economic Development Corporation, the Ottawa Tourism and Convention Authority and l'Association Touristique de l'Outaouais. Together, they are responsible for the management of the tourism industry within the Ottawa-Hull area.

With such a variety of activities in the National Capital Region, it is not surprising that tourism has been a major contributor to the local economy, and it has been growing rapidly in the last several years. One estimate of the economic impact of tourism in the Capital area was approximately $\$ 620$ million for 1997 and supported 13,000 jobs directly. ${ }^{15}$

In order to complete their economic impact assessments, the Ottawa Tourism \& Convention

\footnotetext{
${ }^{14}$ National Capital Commission, Federal Task Force on Cooperative Programming.

${ }^{15}$ Franco Materazzi Consult Inc. and The Corporate Research Group Ltd., Tourism Opportunities Study: Canada's Capital Region, Prepared for REDO, OTCA and l'ATO, March 1997, web site.
} 
Authority currently utilizes various sources of information provided by the sponsoring organizations and the Tourism Economic Assessment Model (TEAM), a computer-based model developed by the Canadian Tourism Research Institute of the Conference Board of Canada. An overview of the economic impact of tourism in the Capital Region for 1998 is provided below.

Table 5. Capital Region Tourism at a Glance - 1998

\begin{tabular}{|l|l|}
\hline \multicolumn{2}{|l|}{ Visitors } \\
\hline Total Person Visits to Ottawa-Hull & $5,678,000$ \\
\hline Same-day Visits & $2,363,622$ \\
\hline Overnight Visits & $3,314,378$ \\
\hline Attendance at Museums & $3,931,336$ \\
\hline Origin of Visits & $4,701,000$ \\
\hline Canada & 519,000 \\
\hline United States & 458,000 \\
\hline Other International & \\
\hline Visits by Accommodation & $1,523,000$ \\
\hline Commercial & $1,791,000$ \\
\hline Private Dwelling & \\
\hline Ottawa Economic Impact & $\$ 1.07$ billion \\
\hline Tourism Economic Activity & $\$ 582.1$ million \\
\hline Contribution to GDP & $\$ 842.8$ million \\
\hline Visitor Spending in Ottawa-Hull & $\$ 783.3$ million \\
\hline Visitor Spending in RMOC & $\$ 159.87$ \\
\hline Average per person per trip & 19,808 \\
\hline Jobs supported by spending & $\$ 141.0$ million \\
\hline Fed. Taxes & $\$ 105.0$ million \\
\hline Prov. Taxes & $\$ 65.2$ million \\
\hline Local Taxes & Puthority, 1998 \\
\hline Source: Ottawa Toursm \& Convention & \\
\hline
\end{tabular}

Source: Ottawa Tourism \& Convention Authority, 1998 Tourism Year in Review, April 1999, pi.

The preceding information suggests 69.2 per cent of all visitors attended a museum during their stay. In the past few years, museums have posted steady a growth, from 3.27 million visitors in 1992 to 3.93 million in 1998, a 20.2 per cent increase. ${ }^{16}$ Although there is a high percentage change in attendance (up to 53 per cent) within the various museums, the overall pattern is that the local museum industry continues to be strong. ${ }^{17}$

\footnotetext{
${ }^{16}$ Derived from Ottawa Tourism \& Convention Authority, 1998 Tourism Year in Review, April 1999, p. 79.

${ }^{17}$ Ibid, p. 79.
} 
Figure 4. Attendance by museum, NCR 1998

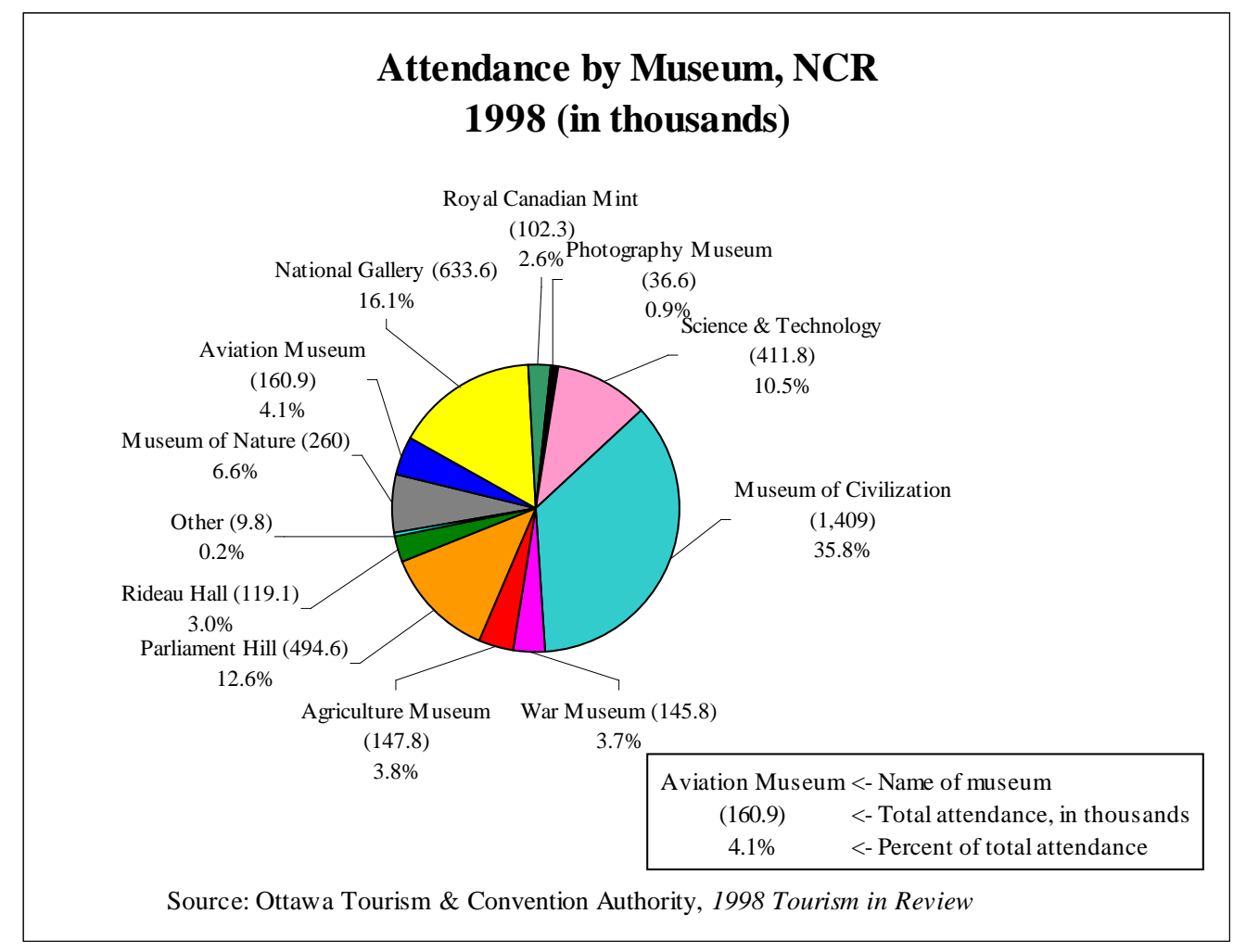

Ottawa-Hull's museums can be either described as major or complimentary heritage institutions. Usually, the larger and more established museums are identified as major institutions but this is not always the case. For example, the Canadian Museum of Civilization Corporation (CMCC) does not fit the norm as it is only a decade old. And, while the Canadian War Museum (CWM) has been operating for a longer period of time, technically it is a sub-entity of the larger and incorporated CMCC. Currently, the CWM is working on detaching itself from CMCC and is awaiting Cabinet approval to receive funding for the construction of a new museum to be relocated away from a crowded downtown setting. 
Figure 5. Total museum attendance, NCR 1992-1998

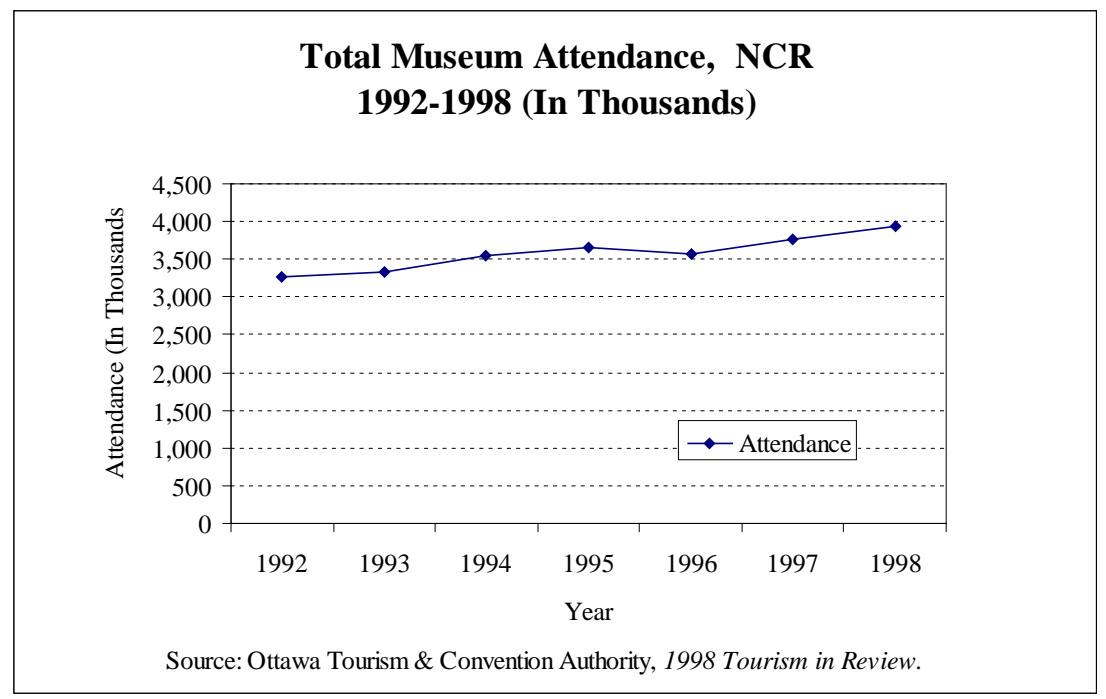

Classified as smaller local heritage institutions, complimentary museums include the Royal Canadian Mint. Such a museum exists because its accessory use is directly linked to a primary use. On a smaller scale, there are local military museums which compliment national institutions such as the Canadian War Museum. These are the regimental museums of The Cameron Highlanders of Ottawa and the Governor General's Foot Guards. These two museums form part of the 62 accredited Canadian Forces museums found throughout the country. Overall, the Ottawa-Hull area has 12 national museums/institutions and over 50 theatres and galleries. Because of the quality of programming, the Capital's museums have become an important cultural destination for visitors.

An economic impact of these Ottawa-Hull destinations can be found in the comparative table presented below. A variety of trends appear when comparing ratios of revenues/attendance with national heritage institutions, Toronto’s Tutankhamun Exhibition and visitor spending in OttawaHull. In particular, the Ottawa ratio $(148: 1)$ is 50 per cent more than the second highest ratio recorded at the Tutankhamun Exhibit $(107: 1)$.

Museum spending is estimated at nearly $\$ 630$ million and accounts for 74.5 per cent of all visitor spending in Ottawa-Hull. Revenues for museums are also considerable. Estimated at nearly \$94 million, these revenues represent nearly 15 per cent of all monies collected when visitors come to the Nation's Capital to visit museums.

When one considers that 69.2 per cent of all persons visiting the area attend a museum, it is not 
surprising to find that an estimated 14,800 out of 19,808 tourism jobs are directly related to museums. The generation of taxes for all levels of government is also worth noting. Out of the \$311.2 million collected for taxes, approximately \$200 million is collected through the various heritage institutions in the Ottawa-Hull area.

Admission fees as a marketing strategy is an issue that all museums must address. This is particularly so as levels of government funding continues to diminish. As discussed below, there are sound reasons for imposing admission fees.

Table 6. Comparative table of economic impact for heritage institutions

\begin{tabular}{|c|c|c|c|}
\hline & $\begin{array}{l}\text { Ratio of } \\
\text { Revenues } \\
\text { vs. } \\
\text { Attendance }\end{array}$ & $\begin{array}{l}\text { Projected } \\
\text { Revenues } \\
\text { /Other }\end{array}$ & $\begin{array}{l}\text { Actual } \\
\text { Revenues }\end{array}$ \\
\hline \multicolumn{4}{|l|}{ National Heritage Institutions } \\
\hline - Community Museums ${ }^{1}$ & $14.103: 1$ & -- & $\$ 50,885,000$ \\
\hline - Art Museums ${ }^{1}$ & $33.021: 1$ & -- & $\$ 190,335,000$ \\
\hline - History Museums ${ }^{1}$ & $21.158: 1$ & -- & $\$ 209,193,000$ \\
\hline - Other Museums ${ }^{1}$ & $25.114: 1$ & -- & $\$ 191,442,000$ \\
\hline - All types of Museums ${ }^{1}$ & $23.877: 1$ & -- & $\$ 641,855,000$ \\
\hline \multicolumn{4}{|l|}{ Toronto Tutankhamun Exhibition } \\
\hline - Out-of-town Overnight ${ }^{2}$ & $107.457: 1$ & -- & $\$ 13,617,250$ \\
\hline - Out-of-town Day ${ }^{2}$ & $37.435: 1$ & -- & $\$ 9,564,314$ \\
\hline - Toronto Residents ${ }^{2}$ & $21.143: 1$ & -- & $\$ 6,323,869$ \\
\hline - All Categories ${ }^{2}$ & $43.307: 1$ & -- & $\$ 29,505,433$ \\
\hline \multicolumn{4}{|l|}{ Ottawa Economic Impact } \\
\hline - Visitor Spending in Ottawa-Hull ${ }^{3}$ & $148.432: 1$ & -- & $\$ 842,800,000$ \\
\hline - Museum Spending in Ott-Hull ${ }^{4}$ & -- & $\$ 628,503,000$ & -- \\
\hline - Revenues for Museums ${ }^{5}$ & -- & $\$ 93,869,000$ & -- \\
\hline - Jobs supported by Museums ${ }^{6}$ & -- & 14,800 & \\
\hline $\begin{array}{l}\text { - Taxes generated from Visitor } \\
\text { Spending (Fed., Prov. and Local) }{ }^{3}\end{array}$ & -- & -- & $\$ 311,200,000$ \\
\hline - All Taxes generated fm Museums ${ }^{7}$ & -- & $\$ 195,774,800$ & -- \\
\hline
\end{tabular}


Notes:

${ }^{1}$ Derived from Statistics Canada, “Profiles of Heritage Institutions,” web site.

${ }^{2}$ Derived from Geoffrey Wall and Chris Knapper, Tutankhamun, p.50.

${ }^{3}$ Derived from Ottawa Tourism \& Convention Authority, 1998 Tourism Year in Review, April 1999.

${ }^{4}$ Derived from Ottawa Tourism \& Convention Authority, 1998 Tourism Year in Review, April 1999. Calculation based on 3,931,336 museum visits at an average per person per trip of $\$ 159.87$.

${ }^{5}$ Derived from applying the "all types of museums” revenues/attendance ratio for national heritage institutions.

${ }^{6}$ Derived from applying a percentage of the museum spending to the total number of jobs created for tourism $(19,808)$.

${ }^{7}$ Derived from applying 69.2 per cent (museum visitations) to the total amount of taxes generated from visitor spending.

\section{Admission fees as a marketing strategy}

Although many festivals do not charge admission fees, the smaller ones in the Ottawa area (such as the Festival Franco-Ontarien and the Jazz Festival) depend entirely on funds from the public to finance their events. The federal museums however are in a different plight. Although there are a number of "free" days throughout the year (such as Canada Day), the great majority of them have admission fee policies in effect. There are several reasons for this. First, this allows for some financial accountability in determining the level of service to be provided to the clientele. Obviously, low attendance may have serious consequences on the institution remaining solvent.

Another reason for instituting admission fees is to reinforce to the public that "there is no free lunch.” Free admission could negatively affect the level of interest. It is important to set the price at a level that will discourage those not really interested while not discouraging interested visitors. When determining price, there are three factors to consider. First, the demand for the service or products. Second, the provision of these goods and services. And third, the perceived value of the goods and services by consumers. If the quality of the goods and services exceeds consumer expectations, customers are likely to return. "Temporary" exhibits are the core of revitalizing the "Product Life Cycle" of each and every museum.

A further trend which is being rapidly accepted and adopted by heritage institutions is the Internet. 


\section{The virtual museum}

A segment of the population that is increasingly becoming important to heritage institutions is the Internet user community. A 1998 Canadian Internet Survey recorded growth rates for on-line users reaching 20 per cent. The Internet has become one of the fastest areas of growth in Canada. There are now approximately 9.5 million Canadian Internet users aged 12 and over and when recognizing users aged 11 and under, the overall total number is estimated to be closer to 11 million. $^{18}$

Canadian penetration rates are also significant at the Census Metropolitan Area (CMA) level.

Table 7. Selected CMAs households with home computers, computer modems and use of the internet

\begin{tabular}{|l|l|l|l|l|}
\hline $\begin{array}{l}\text { Metropolitan } \\
\text { Area }\end{array}$ & Computer & $\begin{array}{l}\text { Ranking out of } \\
\text { 19 CMAs (\% } \\
\text { Computer) }\end{array}$ & Modem & Internet \\
\hline Ottawa & $55.6 \%$ & 1 & $41.4 \%$ & $28.1 \%$ \\
\hline Vancouver & $45.3 \%$ & 3 & $31.9 \%$ & $22.0 \%$ \\
\hline Toronto & $44.3 \%$ & 6 & $28.2 \%$ & $17.4 \%$ \\
\hline Montreal & $31.3 \%$ & 18 & $18.5 \%$ & $10.8 \%$ \\
\hline ALL CMAs & $\mathbf{3 9 . 9 \%}$ & -- & $\mathbf{2 5 . 5 \%}$ & $\mathbf{1 5 . 8 \%}$ \\
\hline Canada & $\mathbf{3 6 . 0 \%}$ & -- & $\mathbf{2 1 . 5 \%}$ & $\mathbf{1 3 . 0 \%}$ \\
\hline
\end{tabular}

Note: Home computers exclude systems that can only be used to play games or are exclusively for business purposes. Modems include both internal and external units. Internet use includes households with home access only.

Source: Statistics Canada, Income Statistics Division, Households Facilities and Equipment, unpublished data, May 1997.

While overall, 36 per cent of Canadian households own a computer, the penetration rate for CMAs is nearly four per cent higher than the national average. The percentage of computer ownership is as low as 31.3 per cent in Montreal and as high as 56 per cent in Ottawa -- a variance of 23.7 per cent. It is worth noting that penetration rates for modems have been calculated at 60 per cent of the penetration rate for computers. The same general trend appears to be true when estimating the Internet penetration rate (60 per cent of the modem rate will give you the approximate rate for the Internet rate). The province of Ontario leads the nation in market

\footnotetext{
${ }^{18}$ A.C. Nielsen Measures the Net, 1998 Canadian Internet Survey, original source quoted in the National Capital Commission, Web Site Statistics Federal Partners.
} 
share of domain name registration while Ottawa has the highest number of internet users per capita at 28.1 per cent, which is slightly more than double the national average of 13 per cent.

What exactly is the significance of the Internet to local heritage institutions? Quite simply, museums are able to supply credible and accurate information. In effect, through the web, interest can be stimulated and questions can be answered. Museums have positioned themselves on the Internet with professionally developed web sites. The museum web site builds a virtual community with other institutions and agencies and generally provides:

- Marketing

- Access to collections, research programs, activities and exhibits

- A gateway for viewers to communicate with staff and volunteers

- Linkages reaching out to different audiences and other institutions

- A purchase point for services and products offered

The Ottawa CMA provides a good example of what can be accomplished. The area's earliest creation of a museum web site involved the Canadian Museum of Civilization Corporation (CMCC) in December 1994. It began as an experiment, and has since become an ambitious venture with additional sites including: the Canadian War Museum, the Canadian Postal Museum, the Canadian Children's Museum, the CMCC Virtual Museum and the Virtual Museum of New France. CMCC's recent strategic alliance with Digital Equipment of Canada Limited was the first of its kind in Canada. ${ }^{19}$ Acting as a catalyst for dramatic changes, it transformed a local museum into national and international information networks. In March 1999, the CMCC's collection went online on the internet with the release of the Cultural Assets Information System (CAIS), offering viewers more than 50,000 historical artifacts and cultural treasures. $^{20}$ The CMCC web site has now grown to one of the largest museum sites, with approximately 25,000 screens of information.

Museum web sites can indeed affect the local economy. When properly developed, a web site can offer a high return on investment. The members of the National Capital Federal Task Force on Cooperative Programming and Marketing reported that for February 1999, an estimated 650,000 visits and 14 million hits were made on their Ottawa web sites. ${ }^{21}$ The definition of a 'hit' is an action on the web site, such as when a user views a page or downloads a file, while a 'visit' is a session of activity (all hits) associated with one visitor to a web site. These reported figures are considered conservative as not all Federal partners provided web site statistics to the Task Force. As more products and services are offered on the web, additional revenues will be

\footnotetext{
${ }^{19}$ Gerard Lewis and Linda Morris, “Marketing or Survival...by Any Other Name...," Canadian Museums Association, Vol. XI, No. 2, Summer 1993, web site.

${ }^{20}$ National Capital Commission, Web Site Statistics - Federal Partners, Ottawa, April 16, 1999.

${ }^{21}$ Figures derived from National Capital Commission, Web Site Statistics - Federal Partners, Ottawa, April 16, 1999.
} 
generated and in turn this should contribute to the overall quality and quantity of what museums have to offer.

In economic terms, if one per cent of 650,000 visitors make an average purchase of $\$ 20$, this will result in approximately $\$ 130,000$ of additional sales per month. The annual contribution is nearly $\$ 1.6$ million of Internet sales and \$240,000 worth of federal and provincial taxes collected. When comparing annual figures for the total number of visits people made to the Capital Region (5.68 million for 1998) to the number of visits made on the museum web sites (estimated at 7.8 million), the outcome is surprising. It appears that the number of virtual visits made on the various Ottawa federal web sites are one third more than the number of visits made to Ottawa during the same period of time.

As part of their 1998 survey, the Ottawa Tourism Year in Review reported that for those visitors who attended a museum, 63.4 per cent had internet access. For those who did not visit a museum, the Internet access percentage was $71.5{ }^{22}$ Following the earlier example of applying one per cent at \$20 person for 2.5 million visitors (63.4 per cent of all visitors who have Internet access) - this will result in approximately $\$ 5$ million of additional annual Internet sales and $\$ 750,000$ worth of potential federal and provincial taxes collected. It is for these reasons that it is believed that the actual effect of the Internet is much higher than reported in this paper. Until statistics are more readily available, it will be difficult to provide more accurate estimates of the economic impact.

\section{Conclusion}

Policies related to the operation of museums as cultural facilities are as varied as running any other business. There is no shortage of ideas for policies which have economic impact on the development of a successful tourism sector. The following are some concluding comments on how various museum policies impact on local economic development. Although some of the comments relate specifically to the Ottawa-Hull case study presented in this paper, they can just as well apply to other communities. It is worth reiterating that well-managed museums can contribute significantly to the community, not only economically but socially as well.

\section{Flexibility of museums}

Museums are flexible in providing both active and passive forms of activity in a variety of settings. While the growth potential exists with affluent individuals who are in their late 40s and over, it is key for heritage institutions to remain flexible and diversified in their approach to planning exhibitions. Varied programs will help ensure that visitors become repeat customers.

\footnotetext{
${ }^{22}$ Ottawa Tourism \& Convention Authority, 1998 Tourism in Review, p. 86.
} 


\section{Greater cooperation with tourism and economic development agencies}

Generally speaking, museums tend to keep to themselves. They should make a better effort in being informed of developments in the tourism industry and the community. Especially important is the ability to better forecast future tourism trends as these specifically relate to museum activity. Cost sharing would be worthwhile for all stakeholders involved. Such efforts would not only represent a cost savings but also work to eliminate duplication.

\section{Federal task force on cooperative marketing}

It is important for federal partners to coordinate their efforts internally prior to working with external partners. A pro-active marketing role by the various partners should continue to be encouraged. This will reduce potential duplication of efforts and maximize promotional campaigns with the aim of increasing overall attendance and revenues.

\section{Canadian forces museums}

These military accredited museums could certainly play a larger role with their federal partners. In particular, the two Ottawa local museums should be invited to the table and be made aware of current and future plans. On the positive side, the regimental museum of The Cameron Highlanders of Ottawa did recently join forces with the Canadian War Museum for a local exhibit. This cooperative effort added local flavour to the commemoration of a national historical event. It is worth remembering that these smaller museums are not competitors with the more established institutions but rather, are complementary.

\section{Admission fees as pay per view}

Visitors should be encouraged to attend permanent exhibits and a pay per view policy should be instituted for all specially arranged exhibitions. It has been shown that increased revenues can be derived from such specialty exhibits. Toronto’s Tutankhamum exhibition provides a successful example; well presented and well managed exhibitions are key to remaining viable.

\section{Need for governance}

Unfortunately, there is often too much red tape involved in managing a museum. Although there is reluctance to streamline the administration, there remains the contentious issue of providing direction in the absence of financial control over the operation. The Canadian War Museum provides such an example. They are currently moving to secure independence and in the process 
attempting to raise sufficient funds to locate at a new site. Having control over administration and finances increases the prospects for remaining competitive. Financial success will mean better opportunities for employment (both full time and part time) and a direct contribution to the local economy.

\section{Internet and museum operations}

The use of Internet is quite prevalent in the Nation's Capital. Because the use of the Internet by museums and viewers alike is a recent phenomenon, there is great potential for further development. The use of the Internet as a generator of revenues has not been fully explored by either major or complementary museums coordinated marketing efforts between heritage institutions will contribute to an expanded market. In effect, the internet provides the opportunity for smaller museums to operate at a profit.

\section{Author's biography}

André Levesque has been practicing economic developer for over ten years. Presently he is Millennium Projects Manager, Directorate of History and Heritage with the Department of National Defence in Ottawa. Previously with the City of Ottawa, his business development experience includes marketing, commercial and industrial development and tourism. He has also served as lecturer and consultant on the Self-Employment and Assistance Program - S.E.A.P. (Human Resources Development Canada). He holds a Master of Arts in Economic Geography from Carleton University.

\section{Bibliography}

Addison, Elizabeth, “Museum Marketing: A Tool for Survival,” Canadian Museums Association, Vol. XI No. 2 Summer 1993 September, web site, http://www.museums.ca/pubs/muse/1993/summer/editorial.htm.

Canadian Museums Association, “About Museums,” Canadian Museums Association, web site, last updated July 20, 1999, http://www.museums.ca/aboutmuseums.htm.

Canadian Tourism Commission, 1999/2000 Communications Plan - Canadian Leisure Market.

The Coopers \& Lybrand Consulting Group Management Consultants, NCR 1988 Festivals Study Final Report, Prepared for the Ottawa-Carleton Board of Trade, February 1989. 
Department of National Defence, Canadian Forces Administrative Orders.

Duhaime, Carole and François Colbert, "Museums and Strategic Marketing -- Research Findings,” Canadian Museums Association, Vol. XI No. 2 Summer 1993 September, web site, http://www.museums.ca/pubs/muse/1993/summer/duhaime.htm.

Foot, David K., Boom, Bust and Echo, Mcfarlane Walter and Ross, Toronto, 1996.

Franco Materazzi Consult Inc. and The Corporate Research Group Ltd., Tourism Opportunities Study: Canada's Capital Region, Prepared for REDO, OTCA and l'ATO, March 1997, web site, http://chomnper.insec.ca/redo/publication/tourism_p2.html.

GJD Townend Consultancy, Report on the Funding of Canadian Forces Museums, Prepared for the Directorate of History and Heritage, National Defence, September 1998.

Kelly, Robert F., "Marketing in Museums," Canadian Museums Association, Vol. XI No. 2 Summer 1993 September, web site, http://www.museums.ca/pubs/muse/1993/summer/kelly.htm.

Laventhol \& Horwath Management Consultants, National Capital Region Tourism Development Study, Prepared for Canada’s Capital Visitors and Convention Bureau, November 1985.

Lewis, Gerard and Linda Morris, "Marketing or Survival... by Any Other Name...," Canadian Museums Association, Vol. XI No. 2 Summer 1993 September, web site, http://www.museums.ca/pubs/muse/1993/summer/lewis.htm.

Linton, Jon, “Tomorrow's Museum Audiences -- Key Challenges to Audience Development,” Canadian Museums Association, Vol. XI No. 2 Summer 1993 September, web site, http://www.museums.ca/pubs/muse/1993/summer/linton.htm.

National Capital Commission, Web Site Statistics - Federal Partners, Ottawa, April 16, 1999.

Ottawa Economic Development Corporation, web site, http://www.ocedco.com

Ottawa Tourism \& Convention Authority, 1998 Tourism Year in Review.

Ottawa Tourism \& Convention Authority, Canada's Capital Region Tourism Update \& Outlook, $1^{\text {st }}$ Quarter 1999. 
Peat Marwick Consulting Group, The Economic Impacts of Artistic and Cultural Activities in the National Capital Region, Draft Report Prepared for National Capital Commission, June 1987.

Statistics Canada, Income Statistics Division, Households Facilities and Equipment, unpublished data, May 1997.

Statistics Canada, The Daily, Heritage Institutions publications released Monday, March 9, 1998, web site, http://www.statcan.ca/Daily/English/980309/d980309.htm.

Statistics Canada, “Profile of Heritage Institutions: 1991-92 to 1995-96,” web site, http://www.statcan.ca/english/Pgdb/People/Culture/arts06.htm.

Velodi, Haridas, "A Review of the Admission Policy at the National Gallery of Canada," July 1998, in partial requirements for the degree of Master of Business Administration, University of Ottawa.

Wall, Geoffrey and Chris Knapper, Tutankhamun in Toronto, Department of Geography Publication Series, No. 17 University of Waterloo, 1981. 